RESEARCH REPORT

\title{
IMPACT OF READING ALOUD ON LANGUAGE ACQUISITION OF MULTILINGUAL CHILDREN
}

\begin{abstract}
Objective

Language acquisition accounts for comprehension, interpretation, and expression of all languages in the child's repertoire. An experimental study consisting of multilingual children between 3:6 and 4:2 demonstrated the impact of reading aloud on language acquisition of $L 3$ in the first six years of life. Children in the study spoke Pushto as first language (L1), Urdu as second language (L2). English was introduced to them as third language (L3), on joining a local school. The proficiency and correlation between the acquisition of $L 3$ via reading out loud and its impact over a period of time on linguistic skills to be assessed, and to obtain data for the effectiveness of the activity to enhance language acquisition of an individual exposed to multiple languages.
\end{abstract}

\section{Method}

Two experimental groups consisting of three children each were instructed by two speech-language therapists and one group was excluded of targeted stimulus. A monthly assessment was completed for the six month duration of the study to determine change in receptive and expressive language skills in L3.

\section{Conclusion}

All children showed an average increase of 16 vocabulary words in L3. Moreover, study revealed an increase in structure and complexity of utterances. The study revealed a strong correlation between linguistic exposure through reading aloud to children and their overall language development. The study reflects that multilingualism enhances overall language and speech development and simultaneously aids in literacy skills.

\section{Keywords}

Multilingualism, English as a second language, language acquisition, literacy skills, child's repertoire, linguistic skills.
Amina A. Siddiqui

Asst. Professor

College of Speech Language \&

Hearing Sciences

Ziauddin University

amina.asif.siddiqui@hotmail.com

\section{Hina Fatima Nazir}

Student Clinician

College of Speech Language \&

Hearing Sciences

Ziauddin University

fnazir4@gmail.com

\section{Rabab Sehr}

Senior Lecturer

College of Speech Language \&

Hearing Sciences

Ziauddin University

rababsehr@gmail.com

\section{Ifrah Shah}

Senior Lecturer

College of Speech Language \&

Hearing Sciences

Ziauddin University

Ifr.shah@gmail.com

\section{Anam Mazhar}

Senior Lecturer

College of Speech Language \&

Hearing Sciences

Ziauddin University

an.khuwaja@gmail.com

\section{Misbah Qadeer}

Senior Lecturer

College of Speech Language \&

Hearing Sciences

Ziauddin University

misbahqadeer@gmail.com

\section{Mariam Taher}

Montessori Directress

Class teacher (Pre - Nursery)

The Arts \& Science Academy

mariamtaher@gmail.com

[Siddiqui AA, Nazir HF, Sehr R, Shah I, Mazhar A, Qadeer M, Taher M. Impact of Reading Aloud on Language Acquisition of Multilingual Children. Pak. J. rehabil. 2015;4(1):23-28] 


\section{INTRODUCTION}

Language is a known as a quintessential trait of human beings that is used by them to communicate and share their ideas, needs thoughts and information. When individual speech sounds are combined to form words following a particular set of rules specified in a language, we see the emergence of a meaningful word. There are an estimated 6912 different languages used in the world having distinct symbols; and rules that combine these symbols and make the language unique. With increased globalization in our world today, there are many languages on the verge of becoming extinct as the new generation is being directed towards languages which are more accepted globally'. Samad S stated that in 2011, that UNESCO released information about 27 languages that were facing extinction; as measures were not being taken to preserve and promote them².

Considering the statistics in Pakistan, multilingualism is a common attribute found in the urban population of Pakistan, serving as an advantage for Pakistanis and aiding their easy adjustment in different parts of the world. However it does require an extra effort imposed by the environment and the individual's own interest to stand out within a population with his abilities and master a diverse range of languages ${ }^{3-5}$.

Studies on language acquisition in human babies have revealed that the development of oral language skills begins as early as in the third trimester of pregnancy, when the fetus' ears are well formed and the auditory pathway has developed ${ }^{6}$. This experience enables the baby to recognize the voice of his/her mother immediately after birth, and discriminate amongst the consonant sounds of his/her native language and those of a foreign language 7.8 . It has also been observed through several researches that from birth till six months of age, an infant is able to discriminate between phonetic contrasts of all languages enabling them to acquire the languages spoken in their environment?. The initial six months are crucial to child language acquisition and development, because it is after the age of 7-9 months that there is a natural reduction in phonemic sensitivity, which enables him/her to build phonemic categories and recognize stress patterns and sound combinations specific to the language they are acquiring ${ }^{10,11}$.

A common misconception in our society is that language and speech are a function originating in the mouth and lips, whereas, actually, it is a complex function performed by the human brain. Numerous researches in neurological development have shown that myelination of the neurons is maximally accomplished by the age of three years, facilitating rapid language acquisition during this period, which then plateaus towards the end of early childhood and completes around puberty ${ }^{12,13}$.

Therefore speech and language therapists emphasize upon singing and reading to the baby right after birth, because it is in this critical period that the foundations of language are laid in the baby's brain $^{14}$. There is no need to wait until the child begins to talk; reading to the baby from early infancy, teaches him/her to recognize the sounds and rhythm of the native language; thus reading books becomes comforting and fun ${ }^{15}$. As children grow up they are able to understand complex narratives, so reading aloud makes complex ideas more accessible and exposes children to vocabulary and language patterns that are not part of the everyday speech that they are exposed to ${ }^{16}$. This helps in the development of literacy skills and makes reading fun ${ }^{17}$. Reading aloud exposes less able readers to the same rich and engaging books that fluent readers read on their own, and entices them to become better readers.Students of any age benefit from listening to an experienced reading of a wonderful book ${ }^{18}$.

Language maturation plateaus around the age of puberty ${ }^{19}$, which is also when myelination is completed. After this period it is a great challenge to acquire a new language as all the phonemic patterns are established in the brain centers and it becomes difficult to discriminate them and map them as easily as they could have been done before.

Multilingualism also known as bilingualism, is the use of two or more languages to communicate and share thoughts, ideas, needs, knowledge and information. This study focuses on two sub types known as, simultaneous bilinguals (mastering two languages at the same time) and sequential bilinguals (when one language is mastered after another) ${ }^{20}$. Language acquisition: is the process by which human babies acquire and develop their innate capacity to perceive and comprehend language, as well as to produce and use words and sentences to communicate effectively with people around them ${ }^{21}$. Literacy skills include the ability to learn all the techniques that are required for reading and writing a language. They consist, of phonological awareness, print awareness and letter - to sound correspondence; and also include skills needed to acquire vocabulary and their spellings as well as reading comprehension ${ }^{22}$.

\section{METHODOLOGY}

\section{Study Design}

A pilot study of a longitudinal cohort of child participants was conducted at a private school located in Karachi. It was designed to facilitate the bilingual (L1 \& \& L2) Pakistani child's acquisition of the English language (L3), as it was the medium of instruction at school. Therefore, sequential bilingualism was 
researched through this study, which was completed with the help of a principal investigator, four research fellows and the class teacher of Pre Nursery, with an essential role as a co-investigator.

The sample was divided into control and experimental groups comprising of equal number of participants and investigators in each group. The child participants in the control group did not receive any additional language stimulus, except for the exposure in the class through their class teacher; as opposed to the experimental group participants. An informal checklist was formulated to assess each child's progress prior to commencement of the study, followed by a mid way assessment after 3 months and then the last assessment at the end of the $6^{\text {th }}$ month.

\section{Rationale}

Simultaneous bilingualism occurs in the early childhood years; and has proved to be a cognitive boon for children in the pre school age, aged between two and six years chronologically. Children above the age of six years also benefit from reading stories aloud to them. Several studies over the last few decades have highlighted the importance of reading to little children, claiming several benefits to the development of language skills in all the four modalities, namely the receptive and expressive repertoires of oral language as well as reading and writing ${ }^{23}$. The responsibility of reading aloud to the child lies on the parents, and they are able to achieve the best results when they consciously establish a routine in the child's everyday life, thereby having a fixed time span for all tasks, including reading aloud. This makes it easy to regulate the habit of reading to children and develops their interest in stories and books. Researchers have mentioned some of the benefits displayed by children as having better receptive language skills in the early years, and higher lexical skills in their expressive repertoires. Children also acquired the second language quicker and with a more native like proficiency when they were exposed to it earlier in lifethrough stories that were read aloud to them followed by role play and pretend play activities. They also had better literacy skills with a greater proficiency in learning word spellings ${ }^{24}$.

\section{Sample Size}

Six students enrolled in Pre - Nursery were chosen randomly from the class, by the class teacher. They were divided into two groups of three children each, forming a control group and an experimental group.

\section{Study Duration}

This study was conducted over a period of six months, where the participant children of the experimental group were exposed to L3 everyday with the investigators, who read books aloud to them, and had a brief conversation about the story read; whilst the children belonging to the control group only received stimulation for L3 within the class, through the teacher.

\section{Inclusion Criteria}

Children who had normal hearing and vision and typically developing milestones were included as study subjects, they were healthy and had no history of any major illness. They were between the ages of 3-6 years and 4-6 years.

Each child was exposed to L1 Pushto, at home namely the native language, whilst L2 Urdu, was prevalent in the extended families, and neighbor hood but not spoken at home; making L1 the dominant language. L3 English was introduced for the first time to the child, at school.

All participants were enrolled in the same class at school, and had same class teacher. These children were enrolled into their school 6 months ago, and were exposed to English as the medium of instruction.

\section{Exclusion Criteria}

Children exposed to L1 (Pushto), and L2 (Urdu) being spoken at home by the family, were excluded from the study, because they, came from a bilingual environment; (simultaneous bilingualism with parallel exposure to both languages).

Gender was not a criterion for inclusion/exclusion of children, in this study.

\section{Assessments and Evaluations}

The class teacher, met and interviewed the parents (mostly mothers), of the children, to determine the lingual status at home. The Primary Investigator observed the children in the presence of their mothers, as well as whilst they were interacting with one another within the class. An assessment of the children's receptive language skills in L2 (Urdu), was made through discourse to determine the inclusion of children in the study.

A formal assessment was also conducted in L3, as the baseline. The content of assessment for L3, as given in the table below, was carefully selected to encompass semantic, morphological and syntactic skills acquired in the early stages of language development, as described by Roger Brown. 


\begin{tabular}{|c|c|c|c|}
\hline \multicolumn{4}{|c|}{ Contest of assessment: Table 1: } \\
\hline $\begin{array}{l}\text { Nominal } \\
(20)\end{array}$ & $\begin{array}{l}\text { Actions/ } \\
\text { instruction } \\
\text { (10) }\end{array}$ & Position(5) & $\begin{array}{l}\text { Dis-cours } \\
(4)\end{array}$ \\
\hline $\begin{array}{l}\text { fish, cup, } \\
\text { tree, apple, } \\
\text { bus, man, } \\
\text { airplane, TV, } \\
\text { ball, eyes, } \\
\text { hand, } \\
\text { flower, } \\
\text { knife, } \\
\text { scissor, } \\
\text { glass, } \\
\text { toothbrush, } \\
\text { shoes, } \\
\text { pencil, } \\
\text { bottle, bag. }\end{array}$ & $\begin{array}{l}\text { Show } \\
\text { me_} \\
\text { clap your } \\
\text { hands, } \\
\text { spin around, } \\
\text { give me_} \\
\text { sit down, } \\
\text { fold your } \\
\text { arms, } \\
\text { Open the } \\
\text { book, } \\
\text { Turn the } \\
\text { page, } \\
\text { Stand up, } \\
\text { tell me the } \\
\text { name of } \\
\text { (What is } \\
\text { this?) }\end{array}$ & $\begin{array}{l}\text { in,on,out, } \\
\text { in front of, } \\
\text { down/ } \\
\text { under }\end{array}$ & \begin{tabular}{|l|} 
used \\
greetings, \\
and \\
information \\
n about \\
personal \\
identity \\
(own\ \\
name, \\
residence, \\
siblings, \\
friends)
\end{tabular} \\
\hline
\end{tabular}

\section{Stimulus used in the experiment (books that were} read aloud)

Reading material was pre-determined and chosen according to the child's language age in L 1 , and cognitive skills.

Books were graded into 4 groups:

- 1st set - lexical development (culturally appropriate pictures)

- 2nd set - lexical development (wider range of pictures)

- 3rd set - story books with rhyming words and books with written sentences punctuated with pictures

- 4th set - Lady Bird reading scheme levels 1 \& 2;

Step into reading level 1 \& 2

Nominals such as colors, numbers, and shapes which were included in the academic instruction in class were eliminated.

\section{Data Collection Procedure}

Children were initially assessed at the start, and reassessed half way through, followed by a final assessment at the end of the 6th month of exposure to reading aloud with the researchers.

Informal assessments were administered in L3 (English), to gauge the communication skills of the selected children. Picture books, flash cards and toys were used to elicit the language sample and determine their language skills.

Towards the end of the study, the children were asked to give one another instructions; they had to place objects according to the positions they were told. And had to name the positions given by the investigator in response to the question "Where is_?"

\section{RESULTS}

\begin{tabular}{|c|c|c|c|c|c|c|c|c|}
\hline & \multicolumn{8}{|c|}{ Control Group } \\
\hline & \multicolumn{4}{|c|}{ Before } & \multicolumn{4}{|c|}{ After } \\
\hline & $\begin{array}{l}\mathrm{NO} \\
\mathrm{MI} \\
\mathrm{NA} \\
\mathrm{LS} \\
(20)\end{array}$ & $\begin{array}{l}\text { ACT } \\
\text { ION } \\
S \\
(7)\end{array}$ & $\begin{array}{l}\text { PO } \\
\text { SIT } \\
I O \\
N \\
(5)\end{array}$ & $\begin{array}{l}\text { UNDER } \\
\text { STANDI } \\
\text { NG } \\
\text { DISCO } \\
\text { URSE } \\
(4)\end{array}$ & \begin{tabular}{|l|} 
NOM \\
INAL \\
$S$ \\
$(20)$
\end{tabular} & $\begin{array}{l}\text { AC } \\
\text { TI } \\
O \\
\text { NS } \\
(7)\end{array}$ & $\begin{array}{l}\text { POSI } \\
\text { TION } \\
\text { (5) }\end{array}$ & $\begin{array}{l}\text { UN } \\
\text { DE } \\
\text { RS } \\
\text { TA } \\
\text { ND } \\
\text { IN } \\
\text { G } \\
\text { DI } \\
\text { SC } \\
\text { OU } \\
\text { RS } \\
\text { E } \\
\text { (4) }\end{array}$ \\
\hline $\mathrm{AL}$ & 6 & 4 & 2 & 2 & 12 & 7 & 3 & 3 \\
\hline AK & 6 & 2 & 2 & 0 & 13 & 5 & 4 & 2 \\
\hline$S Q$ & 4 & 2 & 1 & 0 & 12 & 6 & 3 & 2 \\
\hline
\end{tabular}

\begin{tabular}{|c|c|c|c|c|c|c|c|c|}
\hline & \multicolumn{8}{|c|}{ Experimental Group } \\
\hline & \multicolumn{4}{|c|}{ Before } & \multicolumn{4}{|c|}{ After } \\
\hline & $\begin{array}{l}\text { NO } \\
\text { MIN } \\
\text { ALS } \\
(20)\end{array}$ & $\begin{array}{l}\mathrm{AC} \\
\mathrm{TI} \\
\mathrm{O} \\
\mathrm{NS} \\
(7)\end{array}$ & \begin{tabular}{|l|}
$\mathrm{PO}$ \\
$\mathrm{ITIO}$ \\
$\mathrm{N}$ \\
$(5)$
\end{tabular} & $\begin{array}{l}\text { UN } \\
\text { DER } \\
\text { STA } \\
\text { NDI } \\
\text { NG } \\
\text { DIS } \\
\text { CO } \\
\text { URS } \\
\text { E } \\
(4)\end{array}$ & $\begin{array}{l}\text { NO } \\
\text { MIN } \\
\text { ALS } \\
(20)\end{array}$ & $\begin{array}{l}\text { ACT } \\
\text { ION } \\
S \\
\text { (7) }\end{array}$ & $\begin{array}{l}\text { POS } \\
\text { ITIO } \\
\mathrm{N} \\
(5)\end{array}$ & \begin{tabular}{|l} 
UND \\
ERST \\
ANDI \\
NG \\
DISC \\
OUR \\
SE \\
$(4)$
\end{tabular} \\
\hline $\mathrm{AJ}$ & 9 & 7 & 3 & 2 & 20 & 10 & 5 & 4 \\
\hline $\begin{array}{l}S \\
A \\
S\end{array}$ & 3 & 1 & 1 & 1 & 18 & 8 & 4 & 4 \\
\hline $\begin{array}{l}M \\
H\end{array}$ & 4 & 3 & 2 & 1 & 20 & 10 & 5 & 4 \\
\hline
\end{tabular}

The progress in the control group is attributed to the teacher's use of L3 (English) in class.

It was observed that children, had become confident about their usage of L3 by the end of the eighth week, and they enjoyed the story book activity, they imitated the SLT and would label pictures in English. AJ learnt new words (hedgehog, stroller, mittens); and teacher reported she was using more names of colors, purple, black \& white; SAS and $\mathrm{MH}$ imitated the words spoken to them by the research fellow, and imitated the prosody of words that were difficult. MH used words like house, spoon, and frog. 


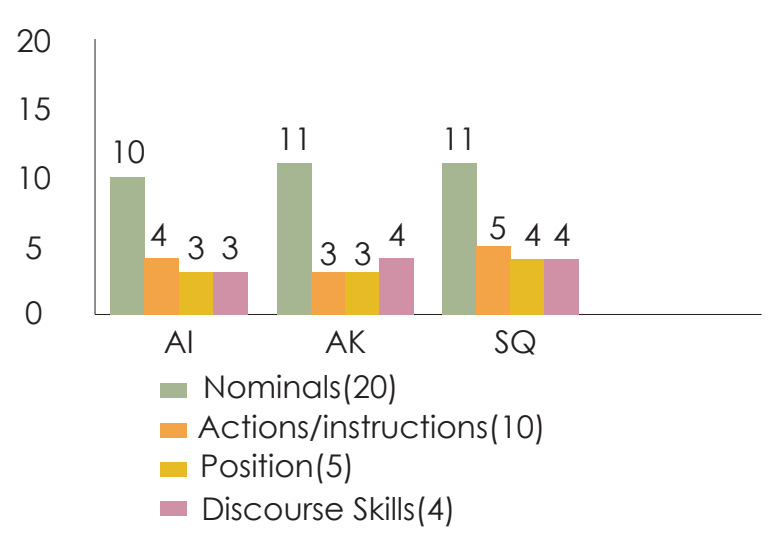

\section{Experimental Group}

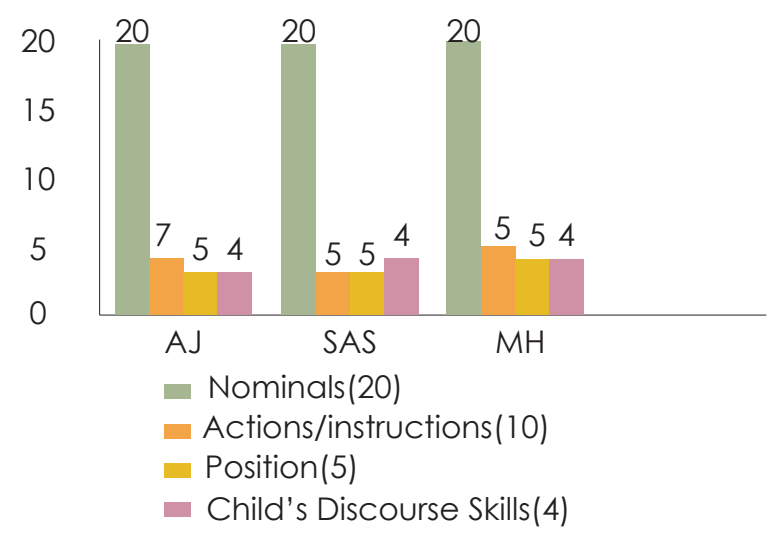

Figure 1 Comparison of $C G$ and EG expressive repertoire

children's discourse skills were judged on the basis of their responses to the 4 questions about their personal identity. When given instructions they had negligible difficulty with word order and order of reference; which had been a problem earlier; e.g. put the pencil in the plate.

They had developed concepts of the descriptive words like, big, small, dirty, clean and learnt body parts like elbow. The teacher reported that the children were quicker to pick up instructions in the class, and did not need visual or physical prompts. E.g. Instructions such as "Throw the tissue in the dust bin" was correctly followed.

\section{Primary outcome}

Average number of words that increased in expressive lexicon was 14. It was observed that children in the experimental groups acquired greater maturity in structure and complexity of utterances as compared to their peers who were not exposed to reading books aloud.

\section{Secondary Outcome}

Individuals had attained an advantage of enhanced participation in class as the teacher reported that the children readily responded to instructions, and required no prompts. Towards the concluding sessions the children had becomefriendlier, and were observed to be more social as they had better developed linguistic and cognitive skills. This experiment also served as a foundation for elevated performance in academics as compared to their peers.

\section{CONCLUSION}

This study emphasizes the importance of reading aloud to children at a young age as it enhances social skills, increases lexicon; and helps stimulate imaginative thoughts and ideas. Thus, it helps in establishing enriched linguistic and cognitive skills influencing class participation and academic performance positively, especially in societies where L3 English is the second (or third) language. Reading activities which engage two or more participants help in building self constraint and increase attention span, hence better peer relationships are formed with a strong bonding. It also lays down foundations for emergent literacy skills, as print awareness instigates maturation of phonological awareness.

Moreover, it has been long established in science and research that the child who comes to school with a large vocabulary does better, than the child who comes to school with little familiarity with the lexicon used in the class; as the instructions are orally presented which makes following class instructions easier 25,26 .

\section{REFERENCES}

[1] Levinson S, Evans N. The Myth of Language Universals: Language diversity and its importance for cognitive science, [Internet], Behavioral and Brain Sciences (in press) Cambridge University Press 2009, Available from : http://www.princeton.edu/ adele/LIN_106:_UCB_files/Evans-Levinson09_preprint.pdf

[2] Siddiqui S. 27 languages face Extinction, The Express Tribune, [Internet], 2011 Mar 16. Available from : $\quad$ http://tribune.com.pk/story/133198/27-languages-face-extinction/

[3] Siddiqui A. section 1: The Study of language Development [unpublished lecture notes]. Normal Language Development 1, Ziauddin University; lecture given $2012 \mathrm{Jul} 20$

[4] Siddiqui A. section 3: Speech and Language Development [unpublished lecture notes]. Normal Language Development 1, Ziauddin University; lecture given 2012 Aug

[5] Nordquist R. Bilingualism [internet]. Cited 2015 Mar 9. available from: http://gram- 
mar.about.com/od/ab/g/Bilingualism.htm

[6] Fetal Hearing: When (and What!) Your Baby Can Hear [Internet]. 2015 [updated 2015 Jan 8; cited 2015 Feb 27] Available from: http://www.whattoexpect.com/pregnancy/fetal-hearing/

[7] Owens R.Language Development - An Introduction 8th edition, Pearson, 2012

[8] Skinner P, Shelton R. SPEECH LANGUAGE AND HEARING: Normal Processes and Disorders. 2nd ed. John Wiley \& Sons Inc. 1984

[9] Rosenback R. Bilingual is better: the advantages of speaking more than one language [internet]. 2014 jan 22

[cited 2015 Mar 10] available from: http://multilingualparenting.com/2014/01/22/bilin$g u a l-i s-b$ - $\quad t$ ter-the-advantages-of-speaking-more-than-one -language/

[10] Babycentre medical advisory board. Reading to your baby. [internet]. Updated 2014 june [cited 2015 Mar 9]. Available from: http://www.babycenter.com/0_reading-to-your-baby_368.bc

[11] Mckay A. What is language Acquisition? - theories, stages and quiz [published lecture notes]. Psychology 101 : Intro to psychology. Study.com (online), available from: http://study.com/academy/lesson/what-is-language-acquisition-theories-stages-quiz.html

[12] Green E. Language Acquisition (Ch. 6/ lesson 7) [published video lecture]. Psychology 101: Intro to psychology. Study.com. Available from: http://study.com/academy/lesson/language-acquisition.html

[13] Roundy L. Stages of Language Development: Pre-Linguistic and Symbolic Language [published video lecture]. Psychology 103: Human Growth and Development. Study.com. Available from: http://study.com/academy/lesson/stages-of-language-development-pre-linguistic-and-symbolic-language.html

[14] Ciccarelli S. 7 Ways Reading Aloud Improves and Enriches your Life. [internet] 2008 Nov 6 [cited 2015 Apr 22] Voice.com. available from: http://blogs.voices.com/voxdaily/2008/11/7_ways_reading_aloud_improves_your_life.html

[15] Fisher-price. Parenting Topics: When should I start reading to my baby? [internet]. Cited 2015 Mar 9 Available from: http://www.fisher-price.com/en_US/playtime/parenting/articlesandadvice/articledetail.html? article=tcm:169-1 7043

[16] Konnikova M. IS BILINGUALISM REALLY AN ADVANTAGE? [Internet]. 2015 Jan 22 [cited 2015 Mar 9].available from: http://www.newyork- er.com/science/maria-konnikova/bilingual-advantage-aging-brain

[17] Gold J, Gibson A. Reading Aloud to Build Comprehension [internet]. Cited 2015 Mar 9, Available from: http://www.readingrockets.org/article/reading-aloud-build-comprehension

[18] Frey, S, Study says reading aloud to children, more than talking, builds literacy; Edsource, Availabe online from : http://edsource.org/2015/study-says-readi n g - a l o ud - to - c h i l dren-more-than-talking-builds-literacy/82045.

[19] Kroll JF, De Groot, ABM, editors. Handbook of Bilingualism : Psycholinguistic Approaches [Internet], Oxfor University Press, 2005, Available from : https://books.google.com.pk/books?id=2fzBDp$\dagger \mathrm{A} 5 \mathrm{~N} M \mathrm{C} \& \mathrm{p} r \mathrm{i} \mathrm{n}+\mathrm{s}$ e $\mathrm{c}=$ frontcover $\# \mathrm{v}=$ onepage $\& \mathrm{q} \& \mathrm{f}=$ false

[20] Wikipedia. Multilingualism [internet]. 2009 sep [updated 2015 mar 3; cited 2015 Mar 9]. Available from: http://en.wikipedia.org/wiki/Multilingualism

[21] Matthiessen $C$. The hidden benefits of reading aloud - even for older kids. Great schools [cited 2015 Apr 22] available from: http://www.greatschools.org/students/7104-read-aloud-to-children.gs

[22] Wikipedia, the free encyclopedia, Language acquisition [internet]. [Modified on 2015 Apr 21; cited on 2015 Apr 22] available from: http://en.wikipedia.org/wiki/Language_acquisition

[23] Gleason JB. The Development of Language. 3rd Edition. Mcmillan Publishing Company; 1989.

[24] Debaryshe BD. Joint picture-book reading correlates of early oral language skill, Journal of Child Language, Volume 20, Issue 02, June 1993, pp 455-461, Copyright (C) Cambridge University Press 1993; DOl: http://dx.doi.org/10.1017/S0305000900008370 (About DOI), Published online: 2008; available from : http://journals.cambridge.org/action/displayA b $s$ t $r$ a $c$ t ? fromPage $=$ online $\&$ aid $=2324372 \&$ fileld $=\$ 0305000$ 900008370.

[25] Bainbridge C. Literacy Skills. About parenting [internet] [cited on 2015 Apr 22] available from: http://giftedkids.about.com/od/glossary/g/literacy.htm

[26] Siddiqui A. section 14: literacy development [unpublished lecture notes]. Normal Language Development 2, Ziauddin University; lecture given 2012 Nov 5 